\title{
IDENTIFICATION AND QUANTIFICATION OF WHEAT ROOTS FLAVONOIDS INOCULATED WITH NATIVE RHIZOBACTERIA
}

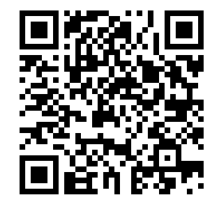

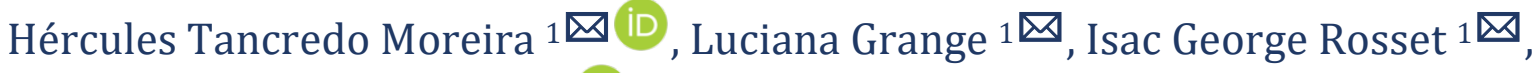 \\ Robson Fernando Missio ${ }^{*} \bowtie$ iD \\ ${ }^{*}$ Federal University of Paraná (UFPR), Palotina, Paraná, Brazil
}

DOI: https://doi.org/10.29121/granthaalayah.v8.i10.2020.2127

Article Type: Research Article

Article Citation: Hércules Tancredo Moreira, Luciana Grange, Isac George Rosset, and Robson

Fernando Missio. (2020).

IDENTIFICATION AND

QUANTIFICATION OF WHEAT

ROOTS FLAVONOIDS INOCULATED

WITH NATIVE RHIZOBACTERIA.

International Journal of Research GRANTHAALAYAH, 8(10), 350-356.

https://doi.org/10.29121/granthaa

layah.v8.i10.2020.2127

Received Date: 16 October 2020

Accepted Date: 31 October 2020

Keywords:

BNF

Standard

HPLC

Bacteria

Triticum Aestivum

\section{ABSTRACT}

In this study, we identified the presence and quantity of flavonoids produced in wheat roots inoculated with rhizobacteria. Our goal is to confirm the efficiency of standard isolates and show new strains with biotechnological potential to promote plant growth. The experiment was carried out with different isolates under inoculation in the following situations: T1-Azospirillum brasiliense; T2-Herbaspirillum seropedicae; T3-Azospirillum brasiliense and Herbaspirillum seropedicae coinoculation; T4-native Enterobacter sp. no 203; T5- native Enterobacter sp. no 208; T6-native Enterobacter sp. no 493; T7-Control only under nitrogen fertilization $(\mathrm{N}+)$; T8-Control without nitrogen $(\mathrm{N}-)$ and bacterial inoculation. Agronomic characteristics were assessed after 42 days of inoculation. Identification and quantification of flavonoids were carried out through HPLC, using an analytical curve with four standards based on Coumarin, Quercetin, Isoflavone and Rutin. Regarding the production of total flavonoids, two (203 and 493) out of the three native strains we tested were statistically significant, exceeding the values obtained from the inoculation of standard strains, which presented association with grasses (Azopirilum e Herbaspirillum). Standard bacteria, when inoculated in isolation, presented, along with those that received $\mathrm{N}+$ treatment, the highest values for length and root and aerial part dry mass. New studies need to be carried out in order to confirm the technological use of these native strains as inoculant, as these bacteria may contribute to Biological Nitrogen Fixation (BNF) in wheat culture, either by competition or synergism.

\section{INTRODUCTION}

Wheat (Triticum aestivum L., from the grasses group) is considered the second most produced grain crop in the world and is an essential constituent of human nutrition worldwide [1]. The Brazilian wheat production in 2019 was approximately 5.2 million tons [2], and the State of Paraná was responsible for more than half of the national production [3].

Several obstacles make production and dissemination of wheat crop throughout Brazil difficult. Such obstacles include technical and biological factors during farming, problems in diseases control [4], other species that are more easily cultivated such as maize and soybean (which are given priority), besides the lack of credit or credit problems and attractive prices [5]. Another limiting factor for the cultivation of many crops, especially wheat, is the cost of

(C) 2020 The Author(s). This is an open access article distributed under the terms of the Creative Commons Attribution License, which permits unrestricted use, distribution, and reproduction in any medium, provided the original author and source are credited. 
fertilizers, particularly the ones containing nitrogen [6]. Therefore, technology development and studies have been carried out in order to make it easier for maize, rice and wheat crops to absorb nitrogen [7]. The lines of research most studied included genetic improvement and increase of associative and beneficial relationships between the plant and nitrogen-fixing microorganisms [8].

The first stage of BNF is extremely important since it is when the bacterium-plant biochemical signaling happens. On that stage, thousands of microorganisms are attracted by the exudates of the roots and quickly approach each other to assemble and/or colonize root tissues [9]. In this highly competitive moment, the most efficient bacteria need to be the first to start the symbiotic fixation process and/or to establish free-living assemblages before the plant starts to establish inefficient or phytopathogenic relationships [10].

Among the most studied plant exudates are those from the flavonoids group [11]. They are phenolic compounds identified as hydrosoluble secondary metabolites present in almost all plant organs and have differentiated functions in the metabolism of plants [12]. Many studies showed the participation of flavonoids in antioxidant and stimulant processes, being beneficial to the plant [13].

Research reported that flavonoids make up most of plants exudates; however, few studies have focused on their production in roots tissues [14]. Moreover, even fewer studies have been carried out to identify the different types of those compounds and their respective functions, especially of those involved in the communication between rhizobacteria and plants [15]. Therefore, we emphasize the importance of the study as it investigates those compounds in wheat culture, which presents low responsiveness to microbial communication and high nutritional demands [16].

Thus, the present study identified the presence and quantity of flavonoids produced in wheat roots inoculated with rhizobacteria, aiming to confirm the efficiency of standard isolates as well as to show new strains with biotechnological potential to promote plant growth.

\section{MATERIALS AND METHODS}

For the experiments, it was chosen to grow CD 150 wheat, early cycle. It is defined as a short plant with medium to high fertility, high grain yield potential and high plant lodging resistance, which makes it tolerate drought periods, and today it represents the most grown cultivar in western Paraná [17].

The standard microorganisms Azospirillum brasiliense and Herbaspirillum seropedicae were obtained from the EMBRAPA soybean crop bank, and the Enterobacter sp. (n- 203, 208 and 493) native strains, from the UFPR-Palotina crop collection. The experiment was carried out following a fully casualized design with 8 treatments (T) and 4 replicates. The plants were inoculated with different isolates and were submitted to the following treatments: T1Azospirillum brasiliense; T2-Herbaspirillum seropedicae; T3-A. brasiliense and H. seropedicae co-inoculation; T4native Enterobacter sp. no 203; T5- native Enterobacter sp. no 208; T6-native Enterobacter sp. no 493; T7-Control only under nitrogen fertilization $(\mathrm{N}+)$; T8-Control without nitrogen $(\mathrm{N}-)$ and bacterial inoculation. All treatments were submitted to fertilization, being used two nutritious solutions previously prepared, considering nitrogen values of $0 \mathrm{mg} \mathrm{L}^{-1}$ (Table 1) and $50 \mathrm{mg} \mathrm{L}^{-1}$ (Table 2).

Sowing was carried out in vases containing medium-grain-sized sand sterilized in autoclave [18]. The seeds were disinfected with a 1\% sodium hypochlorite solution, shaken for 3 minutes, followed by a disinfection with $70 \%$ alcohol, shaken for 1 minute. Those steps were followed by washing with deionized water and sterilization for 6 times straight [19]. After sowing, the vases were taken to a greenhouse at 25을 ${ }^{\circ}$ under controlled humidity (around $60 \%)$.

Table 1: Nutritional solution used in the experiment with absence of nitrogen $\left(0 \mathrm{mg} \mathrm{L}^{-1}\right)$.

\begin{tabular}{|c|c|c|c|c|c|c|c|c|}
\hline Reagente & \multirow{2}{*}{$\mathrm{mg} \mathrm{L}^{-1}$} & $\mathrm{P}$ & $\mathrm{K}$ & $\mathrm{Ca}$ & $\mathrm{Mg}$ & $\mathrm{S}$ & $\mathrm{Cl}$ \\
\cline { 3 - 9 } & & \multicolumn{7}{|c|}{$\mathrm{mg} \mathrm{L}^{-1}$} \\
\hline Sulfato de Magnésio & 530 & & & & 50.35 & 68.90 & \\
\hline Fosfato de Potássio & 250 & 57.5 & 72.50 & & & & \\
\hline Cloreto de Cálcio & 550 & & & 149.65 & & & 265.30 \\
\hline Cloreto de Potássio & 340 & & 176.80 & & & & 159.80 \\
\hline Micronutrientes* & $1 \mathrm{~mL}$ & & & & & & \\
\hline
\end{tabular}

*g $100 \mathrm{~mL}^{-1}$ (FeEDTA-4,21; $\mathrm{ZnSO}^{4}-0,32 ; \mathrm{H}_{3} \mathrm{BO}_{3}-0,12 ; \mathrm{CuSO}_{4}-0,50 ; \mathrm{Na}_{2} \mathrm{Mo}$ 4-0,015; $\mathrm{MnSO}_{4 . \mathrm{H} 20-1,01 \text { ) }}$ 
Hércules Tancredo Moreira, Luciana Grange, Isac George Rosset, and Robson Fernando Missio

Table 2: Nutritional solution used in the experiment with $50 \mathrm{mg} \mathrm{L}^{-1}$ of nitrogen.

\begin{tabular}{l}
\begin{tabular}{|c|c|c|c|c|c|c|c|c|}
\hline Reagente & \multirow{2}{*}{$\mathrm{mg} \mathrm{L}^{-1}$} & $\mathrm{~N}$ & $\mathrm{P}$ & $\mathrm{K}$ & $\mathrm{Ca}$ & $\mathrm{Mg}$ & $\mathrm{S}$ & $\mathrm{Cl}$ \\
\hline & & \multicolumn{7}{|c|}{$\mathrm{mg} \mathrm{L}-1$} \\
\hline Nitrato de Potássio & 357 & 49.98 & & 130.30 & & & & \\
\hline Sulfato de Magnésio & 530 & & & & & 50.35 & 68.90 & \\
\hline Fosfato de Potássio & 250 & & 57.50 & 72.50 & & & & \\
\hline Cloreto de cálcio di-hidratado & 550 & & & & 149.65 & & & \\
\hline Cloreto de Potássio & 10 & & & 52.00 & & & & 47.00 \\
\hline Micronutrientes* & $10 \mathrm{~mL}$ & & & & & & \\
\hline
\end{tabular} \\
\hline
\end{tabular}

After 42 days, the plants were collected and separated the aerial parts and the roots from the portion next to soil. After that, the length of both vegetative parts was measured. The plant material was dried for 72 hours at $45 \circ \mathrm{C}$ in an oven with air circulation and renewal in order to obtain the dry matter (DM).

The extracts for flavonoids quantification were obtained from $300 \mathrm{mg}$ of macerated dry root and submitted to reflux for 15 minutes. Were used $50 \mathrm{~mL}$ of $70 \%$ ethanol as the solvent. A qualitative filter paper was used to obtain the results, storing them in amber bottles in the refrigerator [20].

In order to quantify total flavonoids through spectrophotometry, it was built a 10-point standard curve with Quercetin and added $70 \%$ ethanol as the solvent $\left(0.01 ; 0.05 ; 0.1 ; 0.3 ; 0.5 ; 1.0 ; 3.0 ; 5.0 ; 8.0\right.$ e $\left.10 \mathrm{mg} \mathrm{mL}^{-1}\right)$. The equation of the line presented an R2 over 0.999 . For each $2 \mathrm{~mL}$ of the samples we added $0.8 \mathrm{~mL}$ of $95 \%$ ethyl alcohol, $0.1 \mathrm{~mL}$ of $10 \%$ aluminum chloride, $0.1 \mathrm{~mL}$ of $1 \mathrm{~mol} \mathrm{~L}^{-1}$ sodium acetate, and $2 \mathrm{~mL}$ of distilled water. The solutions reacted for 40 minutes in the absence of light. The same procedures were performed for the negative control samples, and the $2 \mathrm{~mL}$ specimen was replaced by $2 \mathrm{~mL}$ of $70 \%$ alcohol. Then, was read the spectrophotometer (Spectrum SP 2000UV BelFotonics $($ ) at a wavelength of $415 \mathrm{~nm}[21]$.

For the HPLC analysis, it was built an analytical curve consisting of 4 standards based on Cumarin, Quercetin, Isoflavone and Rutin [22] diluted in methanol:water (70:30). In order to make a stock standard solution, were weighted $25 \mathrm{mg}$ and diluted it in $25 \mathrm{~mL}$ of the solvent aforementioned. The curve was composed of 8 distinct concentration points diluted in methanol:water (70:30). These points were: $0.2 \mathrm{mg} \mathrm{L}^{-1} ; 0.4 \mathrm{mg} \mathrm{L}^{-1} ; 1 \mathrm{mg} \mathrm{L}^{-1} ; 5 \mathrm{mg} \mathrm{L}^{-}$ 1; $10 \mathrm{mg} \mathrm{L}^{-1} ; 50 \mathrm{mg} \mathrm{L}^{-1} ; 70 \mathrm{mg} \mathrm{L}^{-1}$; and $100 \mathrm{mg} \mathrm{L}^{-1}$. The linear equation presented a value of $\mathrm{R}^{2}$ above 0.998 , at all events. The samples from all the treatments were filtered through PVDF (Polyvinylidene fluoride) filter and introduced into sterile vials for HPLC analysis (with UltiMate 3000 by Thermo Scientific $®$, using chromeleon 7.1).

For HPLC analysis, were used the following definitions, which were adapted from [23]: gradient system ACN:H3PO4 (M:V) (Ph 2.75) 0-5 min ACN 22\%, 5-6 min ACN 29\%, 6-15 min ACN 29\%, 15-16 min ACN 22\%, 16-20 min ACN 22\%; Phenomenex Column c18 $25 \mathrm{~cm}$ x $4.6 \mathrm{~mm}$ x $5 \mu \mathrm{m}$; sample injection of $20 \mu \mathrm{L}$ in mobile phase of $1.0 \mathrm{~mL}$ $\mathrm{min}^{-1}$, with system pressure at $1800 \mathrm{PSI}$ and run time of $20 \mathrm{~min}$ at $30^{\circ} \mathrm{C}$, using UV-VIS detector at $260 \mathrm{~nm}$.

All data were submitted to variance analysis and a comparison between the obtained averages was made using the t-test to $5 \%$ probability.

\section{RESULTS AND DISCUSSIONS}

Figure 1 shows the amount of total flavonoids as well as the amount of Quercetin and Rutin detected after HPLC quantification. The average value of total flavonoids found was $0.4455 \mu \mathrm{g}$ - 1 root. The treatments with the highest average values were those inoculated with Enterobacter sp. number 203 and number 493, which produced 0.5044 and $0.4935 \mu \mathrm{g} \mathrm{g}^{-1}$ root respectively. These treatments differed statistically from Control N+ (T7), which had the lowest value $(0.3829 \mu \mathrm{g} \mathrm{g}-1$ of root), followed by inoculation with $H$. seropedicae (T2), with a production of $0.3964 \mu \mathrm{g}$ $\mathrm{g}^{-1}$ of root.

The presence of nitrogen in the form of ammonia, in large quantities has significantly reduced the production of chemotactic flavonoids in roots [24]. That is partly because root tissues cease to trigger metabolic cascades (that are regulated by nutritional stress, i.e. nitrogen requirement) under excessive presence of nitrogen [25]. That demand triggers flavonoids production to communicate with beneficial microorganisms, in order to obtain the most assimilable form for plants $\left(\mathrm{NO}_{2}\right)$ and only the required amount of such nutrient [26]. If there is no biochemical communication between roots and microbial community, rhizosphere is weakened on enzymatic functions. That 
may occur because of lack of nitrogen fixers and their nitrogenases, lack of growth promoters, plant hormones production, antibiotics, phosphate solubilization and other processes [27].

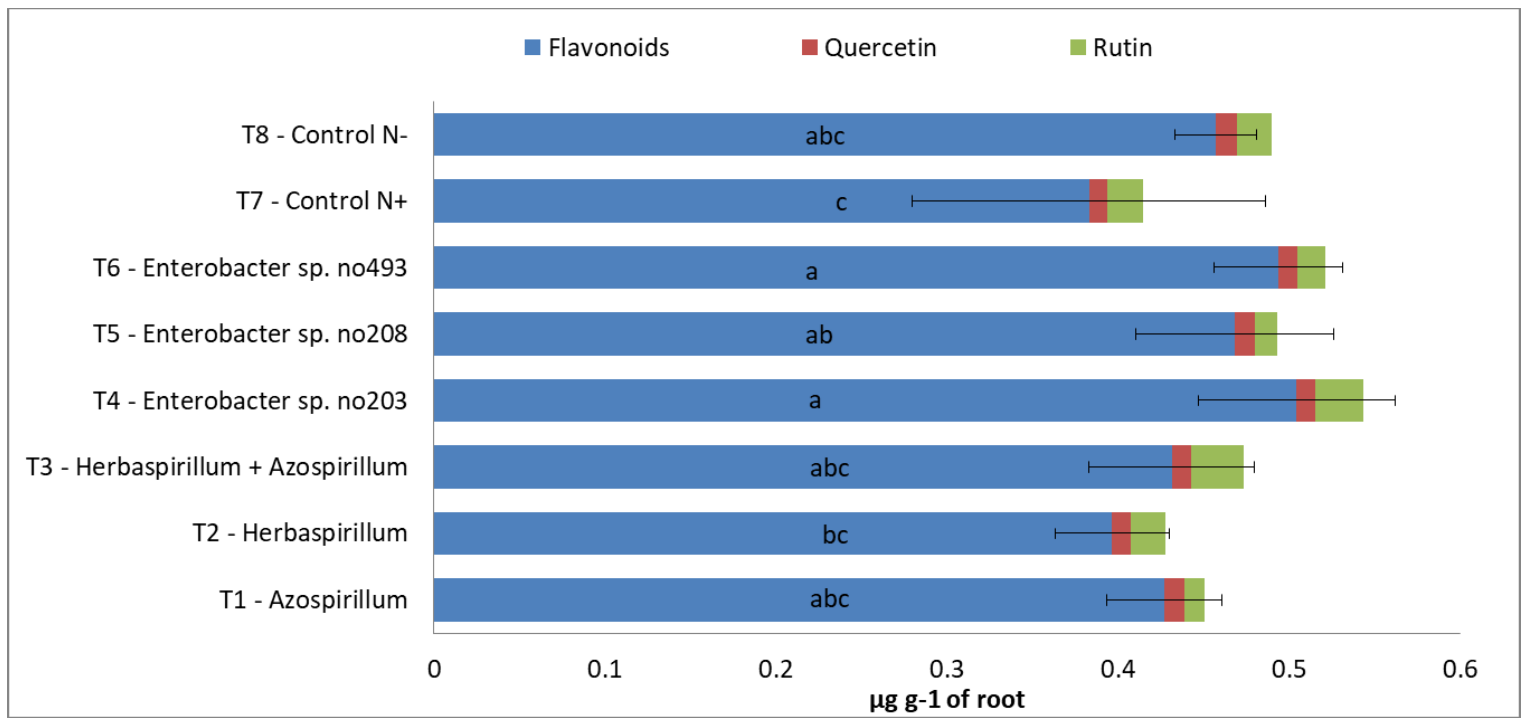

Figure 1: Concentration of total Flavonoids, Quercetin, and Rutin in relation to total in wheat roots (CD150).

With the HPLC analysis (Figure 2), it was possible to quantify Quercetin and Rutin levels within the total flavonoid concentration of plant root, with a percentage that varies depending on treatment: from 2.2 to $2.9 \%$ for Quercetin and from 2.7 to $7.0 \%$ for Rutin. The values of Quercetin in all treatments correspond to an average of $2.55 \%$ of total flavonoids. Whereas, the values of Rutin were quite different. That is the case of the treatments with $A$. brasiliense and $A$. brasiliense in association with $H$. seropedicae, which reached, respectively, $2.7 \%$ and $7 \%$ of total flavonoids of the wheat root.

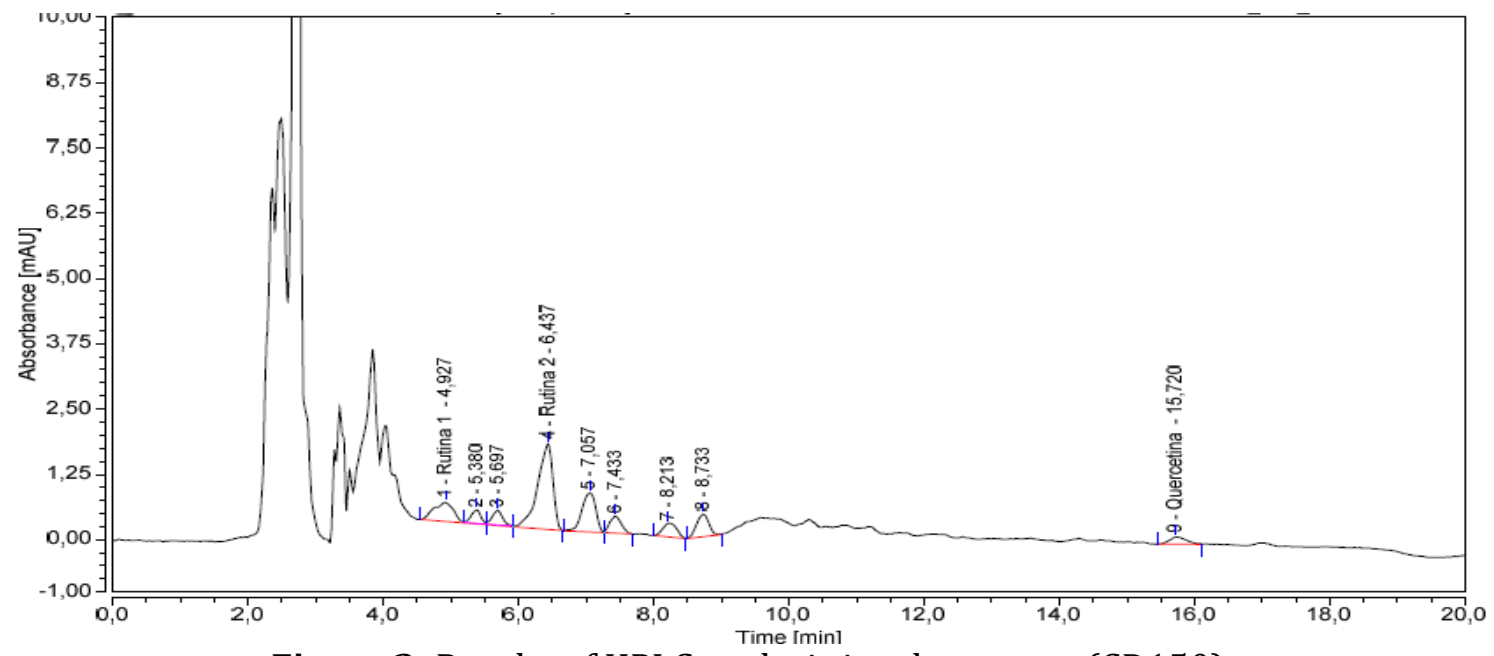

Figure 2: Results of HPLC analysis in wheat roots (CD150).

Flavonoids, such as Quercetin and Rutin, are related to auxin transport, which affects the plant development [28]. Thus, such flavonoids can be considered endogenous regulators of auxin transport [29], protecting the plant from oxidative stress, since they are recognized as structures that sequester free radicals - not only in plants [30].

It is possible that potting conditions, under the lack of nitrogen as a nutrient within the recommendations of Cultivar (CD150), induced the formation of reactive $\mathrm{O}_{2}$ species, causing increase in Quercetin and Rutin levels, as a protective effect against oxidative damage [25]. Different metabolic pathways of responding to biotic and abiotic stresses are normally triggered by genetically-engineered cascades, such as tissue dehydration, reduction of mitotic divisions in meristematic tissue, tissue apoptosis, reproductive tissues abortion, ethylene production and plant and crop death [31]. 
Was observed agronomic differences between root length and root dry matter and aerial dry matter treatments (Table 3). As for root length and root dry matter, the enhance is the treatments T1 - A. brasiliense, T2 - H. seropedicae and T7 - Control $\mathrm{N}+$, which resulted in an average growth of $39.31 \mathrm{~cm}$. The smallest root length was obtained by isolated inoculation with the native bacteria No. 208 (T5) $(29.87 \mathrm{~cm})$, and it did not differ statistically from T3, T4 and T6. On the other hand, studies carried out by our team (not published yet) show that the same strain, coinoculated with standard Azospirillum in maize, was able to increase the vegetative growth by more than $50 \%$ compared to the plants obtained from the positive control (inoculated only with the standard bacteria).

T7 treatment $(\mathrm{N}+$ control) provided the highest root dry matter $(0.8282 \mathrm{~g})$, followed by treatments $\mathrm{T} 1-A$. brasiliense (0.5835 g), T2 - H. seropedicae (0.5274 g) and T5 - Enterobacter sp. 208 (0.5610 g), these three presented no statistical difference between each other. Enterobacter sp. 493 treatment provided the lowest root dry matter (0.3695 g). Those data (Table 3) confirm the efficiency of the standard strain, which were selected, evaluated and exhaustively tested through FBN study with non-legumes. Works from [32] and [33] on wheat and bean crops show that it is possible to verify significant agronomically efficiency of symbiosis and or of associative plants relationships cultivated with BPCVs, properly identified, registered and or recommended by the Ministry of Agriculture as promoters of plant growth.

Table 3: Average values of agronomic variables studied in wheat (CD150).

\begin{tabular}{|c|c|c|c|c|}
\hline Trataments & Root length* $(\mathrm{cm})$ & $\begin{array}{c}\text { Root dry } \\
\text { matter }(\mathrm{g})\end{array}$ & $\begin{array}{c}\text { Aerial } \\
\text { length }(\mathrm{cm})\end{array}$ & $\begin{array}{c}\text { Aerial dry } \\
\text { matter }(\mathrm{g})\end{array}$ \\
\hline T1 - Azospirillum & $39.67 \mathrm{ab}$ & $0.5835 \mathrm{~b}$ & $29.57 \mathrm{c}$ & $54.75 \mathrm{ab}$ \\
\hline T2 - Herbaspirillum & $38.92 \mathrm{ab}$ & $0.5274 \mathrm{bc}$ & $29.90 \mathrm{bc}$ & $49.00 \mathrm{~b}$ \\
\hline T3 - Herbas. + Azospirillum & $34.50 \mathrm{~b}$ & $0.4071 \mathrm{~cd}$ & $32.50 \mathrm{ab}$ & $46.67 \mathrm{bc}$ \\
\hline T4 - Enterobacter sp. $\mathrm{n}^{\circ} 203$ & $32.50 \mathrm{~b}$ & $0.4178 \mathrm{~cd}$ & $32.75 \mathrm{a}$ & $51.25 \mathrm{ab}$ \\
\hline T5 - Enterobacter sp. $\mathrm{n}^{\circ} 208$ & $29.87 \mathrm{~b}$ & $0.5610 \mathrm{~b}$ & $29.90 \mathrm{bc}$ & $54.75 \mathrm{ab}$ \\
\hline T6 - Enterobacter sp. $\mathrm{n}^{\circ} 493$ & $31.37 \mathrm{~b}$ & $0.3695 \mathrm{~d}$ & $34.25 \mathrm{a}$ & $50.50 \mathrm{~b}$ \\
\hline T7 - Control N+ & $39.35 \mathrm{ab}$ & $0.8282 \mathrm{a}$ & $29.37 \mathrm{c}$ & $60.25 \mathrm{a}$ \\
\hline T8 - Control N- & $48.87 \mathrm{a}$ & $0.3944 \mathrm{~cd}$ & $29.00 \mathrm{c}$ & $37.50 \mathrm{c}$ \\
\hline CV (\%) & 20.65 & 17.67 & 6.05 & 12.52 \\
\hline Average & 36.96 & 0.5154 & 30.85 & 50.71 \\
\hline
\end{tabular}

* Averages followed by equal letters do not differ statistically by the t-test ( $\mathrm{p}>0.05)$.

Although not statistically different from other treatments (Table 3), N-control showed the highest average root length $(48.87 \mathrm{~cm})$. This was probably because of direct nitrogen deficiency, which led to metabolism changes in the root cells, causing tissue stretching to search the nutrient in the environment with sandy and poor soil [34]. On the other hand, the weight value of root dry matter for this treatment (T8) was among the lowest: this is a reflection of stretching, which occurs at the expense of the promotion of vegetative growth itself [35].

The highest aerial dry matter values were obtained from treatments T1 (inoculated only with A. brasiliense), T5 (Enterobacter sp., Native 208) and T7 (Control N+), with an average of 56.58 g plant $^{-1}$. Similar results were observed in researches on wheat and inoculation with Azospirillum sp., correlating the amount of dry matter with high nitrogen availability [35].

\section{CONCLUSIONS AND RECOMMENDATIONS}

The next experimental step to test the agronomic potential of the native strains is to co-inoculate them with standard isolates for wheat crop; as well as to evaluate from agronomic and environmental aspects, whether the native strains can be used as collaborators of Biological Nitrogen Fixation (BNF); and or to indicate the need to preserve the native strains in agricultural environment aiming to improve through synergism and or competition the efficacy of strains commercially used as inoculants.

Treatments inoculated with the native strains Enterobacter sp. 203 and 493 (T4 and T6) were the ones with the highest concentration of total flavonoids in the root. Control N+ (T7) delivered a significant reduction of the presence of flavonoids in wheat roots. 
The highest values for length, root dry matter, and aerial dry matter were obtained from treatments inoculated with the isolates type $A$. brasiliense (T1) and $H$. seropedicae (T2), in addition to Control N+ (T7).

In order to continue exploring the agronomic potential of the native strains, it will be necessary to co-inoculate them with standard isolates for wheat crop and to evaluate if they can be used as collaborators of the BNF.

\section{SOURCES OF FUNDING}

This research received no specific grant from any funding agency in the public, commercial, or not-for-profit sectors.

\section{CONFLICT OF INTEREST}

The author have declared that no competing interests exist.

\section{ACKNOWLEDGMENT}

We would like to thank the Conselho Nacional de Desenvolvimento Científico e Tecnológico - CNPq and Universidade Federal do Paraná (UFPR) in special of Laboratório de Análise Instrumental.

\section{REFERENCES}

[1] Camargo, M. P. D .; Moraes, M. H. D. D .; Menten, J. O. M. Efficiency of blotter test and agar culture medium to detect fusarium graminearum and pyricularia grisea in wheat seeds. Journal of Seed Science, 39 (3): 297-302, 2017.

[2] Conab. Acompanhamento safra brasileira de grãos, v. 8, n.1, Safra 2020/21, Brasília, p. 1-77, 2020. Available at: https://www.conab.gov.br/info-agro/safras.

[3] SEAB. Paraná State Secretary of Agriculture and Supply. [Accessed on 14 Feb. 2017] Available at: <http://www.agricultura.pr.gov.br/arquivos/File/deral/pss.xls>

[4] Oliveira, F. 10th Meeting of the Wheat and Triticale Research Commission. National wheat forum, EMATER, Londrina, 2016.

[5] Brum, A. L .; Muller, P. K. The reality of the wheat chain in Brazil: the link between producers / cooperatives. Rural economy and sociology magazine, 46 (1): 145-169, 2008.

[6] Hungary, M .; Campo, R.J .; Mendes, I.C. The importance of the biological nitrogen fixation process for soybean culture: an essential component for the competitiveness of the Brazilian product. Londrina: Embrapa Soy, 2007. 80p.

[7] Dobbelaere, S.; Croonenborghs, A. Effect of inoculation with wild type Azospirillum brasilense and A. irakense strains on development and nitrogen uptake of spring wheat and grain maize. Biology and Fertility of Soils, 36: 284-297, 2002.

[8] Picazevicz, A. A. C .; Kusdra, J. F .; Moreno, A. L .. Maize growth in response to Azospirillum brasilense, Rhizobium tropici, molybdenum and nitrogen. Brazilian Journal of Agricultural and Environmental Engineering, 21 (9): 623-627, 2017.

[9] Zambrano-Moreno, D .; Avellaneda-Franco, L .; Zambrano, G .; Bonilla-Buitrago, R. Scientometric analysis of Colombian research on bio-inoculants for agricultural production. Universitas Scientiarum, 21 (1): 63-81, 2016.

[10] Araújo E. O. Quantification of the contribution of diazotrophic bacteria to nitrogen absorption by corn culture. Doctoral thesis, UFGD. Dourados Mato Grosso Do Sul, 2014.

[11] Kobayashi, H., Naciri-Graven, Y., Broughton, W. J., Perret, X. Flavonoids induce temporal shifts in geneexpression of nod-box controlled loci in Rhizobium sp. NGR234. Molecular Microbiology, 51: 335-347, 2004.

[12] They call, A., Sanguin H. Plant secondary metabolite profiling evidences strain-dependent effect in the Azospirillum - Oryza sativa association. Phytochemistry, 87: 65-77, 2013. 
Hércules Tancredo Moreira, Luciana Grange, Isac George Rosset, and Robson Fernando Missio

[13] Petrussa, E .; Braidot, E .; Zancani, M .; Paresson, C .; Bertolini, A .; Patui, S .; et al. Plant Flavonoids-Biosynthesis, Transport and Involvement in Stress Responses. International Journal of Molecular Sciences. 14: 1495014973, 2013.

[14] Rosa, E. A .; Silva, B. C .; Silva, F. M .; Tanaka, C. M. Am; Peralta, R. M .; Oliveira, C. M. A .; et al. Flavonoids and antioxidant activity in Palicourea rigida kunth, Rubiaceae. Brazilian Journal of Pharmacognosy, 20 (4): 484488, 2010.

[15] Santos J. V .; Ribeiro, P. R. A .; Assis, E. S .; Soares, I. C.; Moreira, F. M. S. Formononetina and phosphorus do not affect the density of associative nitrogen-fixing bacteria in the corn rhizosphere. Encyclopedia Biosphere, 11 (21); 1121-1128, 2015.

[16] Silva, S. R .; Pires, J. L. F. Response of BRS Guamirim wheat to the application of Azospirillum, nitrogen and growth-promoting substances. Agronomic Science Magazine, 48 (4): 631-638, 2017.

[17] Coodetec. Southern product guide, 2015. Details of the cultivar. [Accessed on: 18 Jan. 2017]. Available at: $<$ http://www.coodetec.com.br/downloads/guia-de-produtos-sul-2015.pdf>

[18] Oliveira, K. S. Influence of substrates on the germination of Anadenanthera colubrina seeds under greenhouse conditions. Tree Magazine, 36 (6): 1073-1078, 2012.

[19] Pinheiro, C. G .; Lazarotto M .; Muniz M. F. B .; Redin C.G .; Santos M. V .. Effect of superficial asepsis on germination and fungi incidence in seeds of forest species. Brazilian forest research, 36 (87): 253-260, 2016.

[20] Chabariberi, R. A. O .; Pozzi, A. C. S .; Zeraik, M. L .; Yariwake, J. H. Spectrometric determination of the flavonoids in the leaves of Maytenus (Celastraceae) and Passiflora (Passifloraceae) and comparison with the CLAE-UV method. Brazilian Journal of Pharmacognosy, 19 (4): 860-864, 2009.

[21] Lin, J. Y.; Tang, C. Y. Determination of total phenolic and flavonoid contents in select fruits and vegetables, as well as their simulatory effects on mouse splenocyte ploriferation. Food Chemistry, 101:140-147, 2007.

[22] Veloso, P. A .; Souza, F. M .; Pimenta, A. T. A .; Silveira, E. R .; Lima, M. A. New flavonoids from the root and stem of Platymiscium floribundum vog .. Brazilian Chemical Society (SBQ), 23: 1239-1243, 2012.

[23] Sobrinho, T. J. S. P. Optimization of analytical methodology for the measurement of flavonoids from Bauhinia cheilantha (Bongard) Steudel. New Chemistry, 33 (2): 288-291, 2010.

[24] Xavier, T.F.; Araújo, A.S.F.; Santos, V.B .; Campos, F.L. Inoculation and nitrogen fertilization on nodulation and productivity of cowpea beans. Rural Science, 38 (7): 2037-2041, 2008.

[25] Skonieski, F.R.; Viégas, J.; Martin, T.N .; Nornberg, J.L .; Meinerz, G.R .; Tonin, T.J .; et al. Effect of seed inoculation with Azospirillum brasilense and nitrogen fertilization rates on maize plant yield and silage quality. Brazilian Journal of Animal Science, 46 (9): 722-730, 2017.

[26] Zhang, H. M., Forde, B. G. Regulation of arabidopsis root development by nitrate availability. Journal of Experimental Botany, 51: 342, p. 51-59. 2000.

[27] Hassan, S.; Mathesius, U. The role of flavonoids in root - rhizosphere signalling: opportunities and challenges for improving plant - microbe interactions. Journal of Experimental Botany, 63 (9): 3429-3444, 2012.

[28] Taylor, L. P.; Grotewold, E. Flavonoids as developmental regulators. Current Opinion in Plant Biology, 8: 317 23, 2005.

[29] Lakhanpal, P., Rai, D.K. Quercetin: The Versatile Flavonoid. Internet Journal of Medical Update, 2 (2): 22-37, 2007.

[30] Agati G., Tattini M. Multiple functional roles of flavonoids in photoprotection. New Phytologist, 186: 786-93, 2010.31. Viana, E. M.; Kiehl, J. C. Nitrogen and potassium doses in wheat growth. Bragantia, 69(4):975-982, 2010.

[31] Kharazian, N.; Rahiminejad, M. R. Study of phenolic constituents of Triticum L. (Poaceae) species in Iran. Iranian Journal of Science \& Technology A, 33(4):309-315, 2009.

[32] BRITO, M.P.; MURAOKA, T.; SILVA, E. C. Contribution of biological nitrogen fixation, nitrogen fertilizer and soil nitrogen without the development of beans and cowpea. Bragantia, 70 (1): 206-215, 2011.

[33] Sakakibara, H. Cytokinins: Activity, biosynthesis and translocation. Annual Review of Plant Biology, 57: 431449, 2006.

[34] Silva, A. A.; Delatorre, C. A. Changes in root architecture in response to the availability of phosphorus and nitrogen. Revista de Ciências Agroveterinário, 8 (2): 152-163, 2014.

[35] Souza, W. P. Initial wheat development under nitrogen doses in the Cerrado Red Latosol. Brazilian Journal of Agricultural and Environmental Engineering, 17 (6): 575-580, 2013. 